INTERNATIONAL CENTER FOR PUBLIC POLICY
International Center for Public Policy Working Paper 14-27

June 2014

\title{
Tax Structure and Corruption: Cross-Country
}

\section{Evidence}

\section{Yongzheng Liu}

Haibo Feng

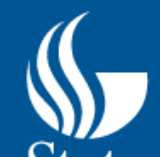

GeorgaState

ANDREWYOUNG SCHOOL

University 



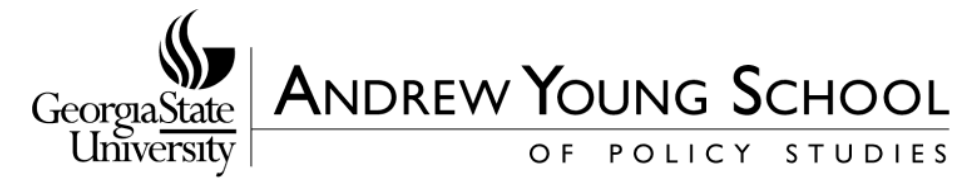

\author{
International Center for Public Policy \\ Working Paper 14-27
}

\section{Tax Structure and Corruption: Cross-Country Evidence}

\author{
Yongzheng Liu \\ Haibo Feng
}

June 2014

International Center for Public Policy

Andrew Young School of Policy Studies

Georgia State University

Atlanta, Georgia 30303

United States of America

Phone: (404) 651-1144

Fax: (404) 651-4449

Email: hseraphin@gsu.edu

Internet: http://aysps.gsu.edu/isp/index.html

Copyright 2006, the Andrew Young School of Policy Studies, Georgia State University. No part of the material protected by this copyright notice may be reproduced or utilized in any form or by any means without prior written permission from the copyright owner. 


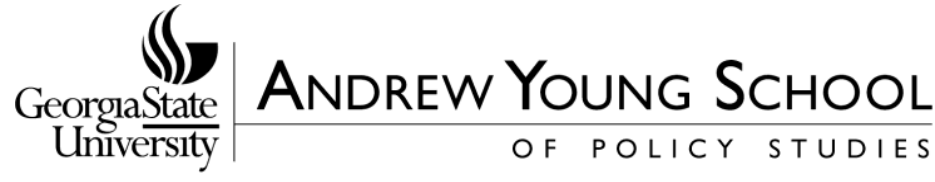

\section{International Center for Public Policy Andrew Young School of Policy Studies}

The Andrew Young School of Policy Studies was established at Georgia State University with the objective of promoting excellence in the design, implementation, and evaluation of public policy. In addition to two academic departments (economics and public administration), the Andrew Young School houses seven leading research centers and policy programs, including the International Center for Public Policy.

The mission of the International Center for Public Policy is to provide academic and professional training, applied research, and technical assistance in support of sound public policy and sustainable economic growth in developing and transitional economies.

The International Center for Public Policy at the Andrew Young School of Policy Studies is recognized worldwide for its efforts in support of economic and public policy reforms through technical assistance and training around the world. This reputation has been built serving a diverse client base, including the World Bank, the U.S. Agency for International Development (USAID), the United Nations Development Programme (UNDP), finance ministries, government organizations, legislative bodies and private sector institutions.

The success of the International Center for Public Policy reflects the breadth and depth of the in-house technical expertise that the International Center for Public Policy can draw upon. The Andrew Young School's faculty are leading experts in economics and public policy and have authored books, published in major academic and technical journals, and have extensive experience in designing and implementing technical assistance and training programs. Andrew Young School faculty have been active in policy reform in over 40 countries around the world. Our technical assistance strategy is not to merely provide technical prescriptions for policy reform, but to engage in a collaborative effort with the host government and donor agency to identify and analyze the issues at hand, arrive at policy solutions and implement reforms.

The International Center for Public Policy specializes in four broad policy areas:

- Fiscal policy, including tax reforms, public expenditure reviews, tax administration reform

- Fiscal decentralization, including fiscal decentralization reforms, design of intergovernmental transfer systems, urban government finance

- Budgeting and fiscal management, including local government budgeting, performancebased budgeting, capital budgeting, multi-year budgeting

- Economic analysis and revenue forecasting, including micro-simulation, time series forecasting,

For more information about our technical assistance activities and training programs, please visit our website at http://aysps.gsu.edu/isp/index.html or contact us by email at hseraphin@gsu.edu. 


\title{
Tax Structure and Corruption: Cross-Country Evidence
}

\author{
Yongzheng Liu* \\ School of Finance \\ Renmin University of China
}

\author{
Haibo Feng \\ School of Economics \\ Jinan University
}

This Version: March 2014

\begin{abstract}
The determinants of corruption have long been an important subject for research in the fields of economics and political science. The literature has identified a wide range of factors that cause corruption; however, little research has been done on how the design of government policy influences corruption. We advance a new factor, the tax structure being measured as both tax mix and tax complexity, as another potential cause of corruption, and present strong supporting evidence by using a large sample of countries over the period 1995-2009. Our findings indicate that: (1) countries relying more heavily on direct taxes tend to enjoy a lower level of corruption, as opposed to countries with higher reliance on indirect taxes; and (2) countries with more complex tax systems tend to have a higher level of corruption, as opposed to countries with less complex tax systems. These results are robust across alternative measures of corruption and tax structure, and alternative estimations with and without correcting the potential endogeneity issue of the tax structure variables.
\end{abstract}

Keywords: Tax Structure; Direct versus Indirect Taxes; Tax Complexity; Corruption JEL Classifications: D73, H20

\footnotetext{
${ }^{*}$ Corresponding author; E-mail: yongzheng.liu@ruc.edu.cn. This paper is supported by Program for New Century Excellent Talents in University (NCET-13-0537) of the Ministry of Education of China. We would like to thank Violeta Vulovic for sharing some of the tax variables data used in this paper. Special thanks to two anonymous referees and the Editor for very helpful comments and suggestions that substantially helped improve the paper.
} 


\section{Introduction}

As a worldwide phenomenon, corruption has received a great deal of attention from academic, policy, and media circles in the past decades. The growing interests in this topic along recent empirical work have largely improved our understanding on various aspects of this issue, especially corruption's determinants. The current literature has identified a wide range of factors that may potentially cause corruption in a country. These include economic and demographic factors (e.g., Fisman and Gatti, 2002; Ali and Isse, 2003), political and institutional factors (e.g., Kunicová and Rose-Ackerman, 2005; Lederman et al., 2005; Chang and Golden, 2007; Escaleras et al., 2010), judiciary system and bureaucratic factors (e.g., Brunetti and Weder, 2003; Damania et al., 2004), and geographical and cultural factors (e.g., La Porta et al., 1999; Treisman, 2000; Paldam, 2002). ${ }^{1}$ Throughout these studies, and in particular for empirical studies, one common feature is that they tend to emphasize the exogenous factors that determine corruption, which are generally out of the direct control of governments. To date, little is known on how the design of government policy potentially affects the level of corruption in a country, even though there is increasing recognition on its importance to address corruption through a better design of taxes and expenditures and their administration (Chand and Moene, 1999). Perhaps the most relevant and welldiscussed literature in this regard is on the effect of fiscal decentralization, for which its net impact on corruption is still theoretically unclear and open to empirical examination (e.g., Treisman, 2000; Fisman and Gatti, 2002; Ali and Isse, 2003; Lederman et al., 2005; Kunicová and Rose-Ackerman, 2005; Goel and Nelson, 2011).

This paper empirically investigates the relationship between tax structure and corruption, where tax structure is captured by both the overall mix of direct versus indirect taxes and the complexity of the tax system. We aim to contribute to the literature by offering a novel determinant for corruption - tax structure, which is more directly controlled by

\footnotetext{
${ }^{1}$ See Seldadyo and de Haan (2006) and Gunardi (2008) for a detailed review on the general determinants of corruption.
} 
governments. ${ }^{2}$ In theory, tax structure matters because, as we illuminate more clearly in the next section, direct taxes versus indirect taxes and a less complex tax system versus a more complex tax system impose different levels of visible tax burden on taxpayers. This difference in the "visibility" of tax burden implies important consequences for taxpayers' voting behaviors and government activities, which in turn affects corruption. We test this hypothesized relationship between tax structure and corruption by utilizing a large sample of countries covering both developed and developing economies over the period 1995-2009. We find strong evidence for our argument that: (1) countries relying more heavily on direct taxes tend to enjoy a lower level of corruption, as opposed to countries with higher reliance on indirect taxes; and (2) countries with more complex tax systems tend to have a higher level of corruption, as opposed to countries with less complex tax systems. These results are robust across alternative measures of corruption and tax structure, and alternative estimations with and without correcting the potential endogeneity issue of the tax structure variables.

The rest of the paper is organized as follows. Section 2 discusses simple theoretical hypotheses that motivate and guide our empirical analysis. Section 3 sets up the empirical methodology and discusses the data. Section 4 presents the empirical results. Finally, section 5 concludes.

\section{Theoretical Hypotheses}

Our starting point to link the impacts of tax structure on corruption is mainly through the fiscal illusion hypothesis. Fiscal illusion refers to a systematic misperception of tax burden that may significantly distort the behaviors of the voters. Various elements of the tax structure have been claimed to potentially cause this kind of misperception; among them two of the most important elements are the relative reliance on direct versus indirect taxes in the tax system and the complexity of the tax system (Mill, 1848; Buchanan, 1967; Buchanan

\footnotetext{
${ }^{2}$ Studies in the reverse direction in investigating the impacts of corruption on taxation are somehow attracting more attention in the current literature. See, for example, Barreto and Alm (2003); Thornton (2008); Pani (2011) and Alon and Hageman (2012).
} 
and Wagner, 1978). ${ }^{3}$ More specifically, it is argued that taxpayers may systematically underestimate tax burden from indirect taxes as compared to direct taxes. Since the subjects of direct taxes are mainly the income and wealth of the taxpayers, which endow this type of taxes with more transparency and less likelihood to shift tax burden from one to another; thus, the actual tax prices for public programs can be estimated more accurately when they are financed by direct taxes. By contrast, indirect taxes are incorporated into, and therefore "hidden" in the prices of goods and services, which makes the actual tax burden less likely to be detected by taxpayers, and so results in an underestimation of the costs for providing public goods and services.

Closely related to the relative reliance on direct versus indirect taxes is another main source of perception error-tax complexity. As tax system becomes more complex, it is increasingly difficult for taxpayer to determine the actual "tax-price" of public outputs - and the more likely that they will underestimate the tax burden associated with public programs (Buchanan, 1967; Wagner, 1976). Even if taxpayers can identify the various tax sources, the marginal costs of procuring full information may quickly exceed any marginal benefits. Consequently, the more complex the tax system, the larger will be the underestimation of actual tax burden of public sector activities (Dollery and Worthington, 1996).

The underestimation of actual tax burden resulting from a higher reliance on indirect taxes and/or a more complex tax system implies important consequences that are related to corruption. First, it leads to an underestimation of the tax-price of public expenditure, and therefore results in voting behavior favoring larger public expenditures than what would otherwise be chosen under perfect information (e.g., Wagner, 1976; Craig and Heins, 1980;

\footnotetext{
${ }^{3}$ Income elasticity of the tax system is generally believed to be another main element in the tax system that gives rise to fiscal illusion. The perceptual bias originated from this source is due to the inability of taxpayers in distinguishing between increases in taxes derived from a general growth in income, and those associated with higher income tax rates; therefore, countries with high income elasticity tax systems generally accelerate the political approval of the sustainability of more expenditures (Buchanan, 1967; Craig and Heins, 1980; Baker, 1983). The main problem surrounding past empirical studies of the income elasticity hypothesis is that researchers are frustrated by the lack of a suitable measure of income elasticity (Dollery and Worthington, 1996). This is especially true for cross-country studies, and for this reason, we do not explore this point further in this paper.
} 
Misiolek and Elder, 1988; Heyndels and Smolders, 1995). The expansion of government expenditure may thus create more opportunities for corruption (e.g., Goel and Nelson, 1998; Ali and Isse, 2003; Alesina and Angeletos, 2005). Second, the underestimation of tax burden may ease the "pain" from paying taxation, which in turn creates less incentive for taxpayers to oversee government operations and restrain government misconducts. In the extreme case, they may even abandon their rights to do so if they do not feel any tax burden at all. Lastly, even if taxpayers have the interests to monitor the behaviors of governments, they may find it difficult to do so for the same reason that generates fiscal illusion-incomplete information. As pointed out by Downs (1957), due to incomplete information, there will typically be little effort made by individual taxpayer to learn about government programs, since the costs involved would largely exceed the benefits he can obtain. ${ }^{4}$ In summary, we have the following two hypotheses.

Hypothesis 1 Countries relying more heavily on indirect taxes tend to have a higher level of corruption than other countries relying more heavily on direct taxes.

Hypothesis 2 Countries with more complex tax systems tend to have a higher level of corruption than other countries with less complex tax systems.

\section{Empirical Methodology and Data Description}

In this section, we discuss the empirical strategy with the objective of testing the previous hypotheses we proposed. We link the relationship between tax structure and corruption using a fairly large sample built with information from 150 countries for 1995-2009. As is also now standard in the empirical studies of corruption (e.g., Treisman, 2000; Fisman and Gatti, 2002), we focus on the cross-country regression for two reasons. First, corruption varies much more across countries than over time, and so this variance cannot be explained by

\footnotetext{
${ }^{4}$ Beyond the channel of fiscal illusion, there are other ways through which tax structure may influence corruption. For example, the more complex the tax system, the less transparent the tax system will be, which provides more discretion for officials and creates more opportunities for corruption.
} 
panel data techniques that typically eliminate cross-country effects and focus exclusively on the within-country relationship. Second, we do not expect a year-to-year change between tax structure and corruption since the ratio of direct versus indirect taxes is likely to be affected by short-run business cycles and the complexity of the tax system is generally stable for long periods of time. Hence, focusing on the average values of our variables will reduce the short-run fluctuations and allow us to examine the long-run relationship between tax structure and corruption.

\subsection{Specification}

The basic specification we employ here takes the simple form,

$$
\text { Corruption }_{i}=\alpha+\beta T S_{i}+\mathbf{X}_{i} \delta+\varepsilon_{i}
$$

where $i$ represents a country; $\alpha$ is an intercept; and $\varepsilon$ is error term. Dependent variable Corruption is a corruption index measured by the Transparency International (TI) or the Worldwide Government Indicators (WGI) or the International Country Risk of Guide (ICRG). TS is our measure of tax structure that is captured by both the overall tax mix and the complexity of the tax system. The former is defined as the ratio of direct taxes to indirect taxes. The latter is defined as the length of time that a representative firm must spend to meet its tax obligations. ${ }^{5}$ As summarized in Hypotheses 1 and 2 , we expect $\beta<0$ if the tax structure is measured by the ratio of direct taxes to indirect taxes, and $\beta>0$ if the tax structure is measured by the complexity of the tax system.

As control variables $\mathbf{X}$ we seek to capture the general economic, demographic, political, and cultural factors of significance in determining corruption. This leads to the inclusion of income level, population density, openness, democracy, government size, federalism and

\footnotetext{
${ }^{5}$ For a more detailed discussion, see subsection 3.3. It should be noted that in order to test the robustness of our results, we also employ alternative measures for both tax mix and tax complexity in the regressions, which are also discussed in subsection 3.3 .
} 
decentralization, and Internet diffusion in the baseline regression. Income level of a country, proxied by GDP, is used to control for structural differences across countries. It is generally believed and found that an improvement in income will contribute to a lower level of corruption, as the demand of corruption will fall and more anti-corruption resources will also be available as income rises (e.g., Fisman and Gatti, 2002; Gunardi, 2008). Population density is a proxy of country size, which is argued to have a positive effect on deteriorating corruption, as larger countries exploit economies of scale in the provision of public servicesresulting in a lower ratio of public services per capita and making individuals more likely to bribe bureaucrats "to get ahead of the queue" (Alesina and Wacziarg, 1998; Fisman and Gatti, 2002). Openness, which is calculated as the ratio of imports to GDP, is generally expected to be negatively associated with corruption. This is so because higher levels of openness mean lower level of restriction on international trade, while the presence of such restrictions has usually been claimed to offer opportunities to bribe (e.g., Broadman and Recanatini, 2001; Knack and Azfar, 2003). Democracy has long been believed to contribute to less corruption, as illicit government behavior can be prevented only when basic political rights are effectively guaranteed to citizens (e.g., Treisman, 2000). It is measured by the average of political rights and civil liberties provided by the Freedom House. ${ }^{6}$ Note that it is rescaled to take values from 0 to 1 with larger values implying more democracy. Government size, measuring as the share of government consumption in GDP, is put forward as a main determinant of corruption, though its impact has been found to be mixed in the literature (e.g., Kotera et al., 2012). Government structure, usually proxied by federalism or decentralization, is another important factor that has been examined quite often as a determinant of corruption in the literature, though its net impact is neither theoretically nor empirically clear (e.g., Treisman, 2000; Fisman and Gatti, 2002). The former is a dummy variable for the presence of a federal institution; the latter is defined as the subnational share of total government spending. Recent studies also highlight the significance of Internet diffusion in

\footnotetext{
${ }^{6}$ In the Freedom House, both "political rights" and "civil liberties" are originally scaled from 1 (most free) to 7 (least free).
} 
controlling corruption through a few variety of ways (e.g., Andersen et al., 2011; Goel et al., 2012). For instance, Internet accelerates the spreading of information, which increases the risk of detection for politicians and public officers' misconducts. This variable is calculated as the number of Internet users per 100 people. As a robustness check, we also include a series of other economic and socio-demographic factors that have been argued to be important determinants of corruption. This includes inflation, human capital, and female labor force participation. Inflation is argued to increase monitoring costs, which can lead to more corruption (Braun and Di Tella, 2004); economies with high human capital are generally associated with low levels of corruption as found in (Ali and Isse, 2003; Brunetti and Weder, 2003); female labor force participation rate may affect corruption through various ways, for instance, women may be brought up to be more honest or more risk averse than men, or even feel there is a greater probability of being caught (Swamy et al., 2001). In addition, we also include other political and cultural variables for further robustness checks, including a dummy for English legal origin, a dummy for colonial heritage, and ethnic fractionalization. English legal origin matters because the greater protections of property against the state embodied in common law systems (found mostly in Britain and its former colonies) improve various aspects of government performance, including reducing corruption (La Porta et al., 1999); countries that have been colonialized tend to suffer from corruption for the divisive nature of the society left by colonial masters (Tavares, 2003; Gurgur and Shah, 2008); lastly, highly fragmented countries are likely to be more corrupt, as there are fewer centralized forces and agencies to enforce honesty (Mauro, 1995; Lederman et al., 2005). ${ }^{7}$

\subsection{Endogeniety}

An important concern in estimation equation (1) is that of the potential endogeneity of tax structure. This issue may arise due to the fact that increasing the share of indirect taxes or the complexity of the tax system is indicative of a greater exploitation of fiscal illusion

\footnotetext{
${ }^{7}$ It should be noted that the evidence on the relevance of these additional variables are, in general, mixed in the empirical literature.
} 
strategies by policy makers (Pommerehne and Schneider, 1978; Dollery and Worthingtong, 1999). Therefore, it is possible that policy makers may intentionally decide the relative reliance on direct versus indirect taxes and the complexity of the tax system based on their interests to create opportunities for corruption. A more subtle argument for the existence of endogeneity is implied by the finding in Barreto and Alm (2003). They argue that the presence of corruption affects the optimal mix between consumption and income taxation in a way that a corrupt economy relies more heavily on consumption taxes than on income taxes, relative to an economy without corruption. This is because in a corrupt economy, both public and private agents pay consumption taxes but only the private agent pays income taxes, and so shifting the tax mix from income taxes toward consumption taxes would raise the private agents' welfare.

In order to circumvent the endogeneity issue, we use an instrumental variable approach. We modify Lee and Gordon (2005)'s approach to instrument our tax structure variable by using the initial level of the corresponding weighed average of tax structure from neighboring countries (weighed by both the contiguity ${ }^{8}$ and the inverse of distance between two countries) as of $1995 .^{9}$ The validity of these instruments is justified by the conventional tax competition and tax mimicking literature, which argues that the design of tax structure in a country will be correlated with the design of tax structure in the neighboring countries, due to the fact that countries compete or mimic their tax policies for attracting mobile tax bases. Given that it takes time for a country to response to the change of tax policies in other countries, it is logical to expect that a country's tax structure is associated with the initial level of tax structure in the neighboring countries. However, average corruption in later years in a country should virtually have no significant impact on the design of tax system of the neighboring countries in the initial year. It is this favorable feature that makes the weighted average tax structure in neighboring countries in the initial year otherwise a good instrument

\footnotetext{
${ }^{8} \mathrm{~A}$ value of 1 is assigned if two countries share the same border and 0 otherwise.

${ }^{9}$ As we will discuss more carefully in subsection 3.3, the data for our measure of tax complexity is only available from 2006 and onward, so the instruments for this variable are the weighted average of tax complexity from neighboring countries as of 2006 .
} 
for tax structure in the home country. ${ }^{10}$

\subsection{Data Description}

The dataset covers 150 countries for the average values over the period 1995-2009. ${ }^{11}$ Data are derived from a wide range of sources. Table A1 in the Appendix provides a detailed description and sources of the variables, while their summary statistics are reported in Table 1. Below, we explain the measurements of our key variables, corruption and tax structure, in further detail.

To begin with, we employ the Corruption Perception Index (CPI) constructed by Transparency International as our principal measure of corruption. CPI ranks countries based on how corrupt their public sector, including public official, civil servants and politicians, is perceived to be. It is a composite index that is constructed by aggregating various perceptionbased indicators of corruption collected by a variety of reputable institutions. As highlighted by Treisman (2000), one appealing reason for the use of this index is that despite the significant difference in methodologies and inputs, the component surveys and ratings from which the CPI is constructed are highly correlated among themselves, which "reduces the risk that one is analyzing the quirks or guesses of individual organization" (Treisman, 2000, p410). However, like other perception-based indices, CPI does not measure corruption directly and so it suffers from the questions surrounding how accurate perceptions are. As a way to deal with this issue, we introduce two alternative corruption indices, the Worldwide Governance Indicators (WGI) published by a team led by Daniel Kaufmann at the World Bank and the International Country Risk Guide (ICRG) produced by the firm Political Risk Services, that are constructed by different methods to compare our principal measure of corruption. Similar to CPI, the WGI is also a type of "poll-of-polls" corruption index, as it is aggregated from various corruption indicators that are provided by a number of survey institutes,

\footnotetext{
${ }^{10}$ It should be noted that we also tried the mean of the weighted average tax structure in neighboring countries for the observed period as alternative method to calculate instruments, the regression results are very close to what we present below in section 4 .

${ }^{11} 1995$ is the earliest year that our principal measure of corruption index is calculated.
} 
think tanks, non-governmental organizations, international organizations, and private sector firms. It captures the perceptions of the extent to which public power is exercised for private gain, including both petty and grand forms of corruption. Instead, the ICRG is a direct polled-based index that is assessed by international experts. It is meant to capture "the likelihood that government officials will demand special payments, and the extent to which illegal payments are expected throughout lower levels of governments" (Fisman and Gatti, 2002, p329). It should also be noted that we rescale all our measures of corruption to take values between zero (least corrupt) and one (most corrupt).

Consistent with our theoretical reasoning in section 2, we measure the tax structure along two dimensions: the overall mix between direct taxes and indirect taxes and the complexity of the tax system. We define direct taxes as those that may be adjusted to the individual characteristics of taxpayers and indirect taxes as those that are levied on transactions irrespective of the buyer or the seller. Thus, direct taxes include personal income taxes, corporate income taxes, and social security and payroll taxes. Indirect taxes include property taxes, general taxes on goods and services, excise taxes, and custom duty. Data for these various tax variables are taken from the Government Finance Statistics of the International Monetary Fund (GFS-IMF) and OECD revenue statistics.

The complexity of the tax system is proxied by the length of time that a representative firm must spend to meet its tax obligations. This includes the time taken to complete all necessary tax forms (including corporate income taxes, sale taxes, labor taxes, and etc.), time to prepare accounts or calculations for tax purposes that would not be covered by regular accounting work, and the time needed to make the payment online or at the tax office. The data are derived from the World Bank Doing Business Survey. It was compiled through a survey of accountants and tax lawyers in 189 countries. ${ }^{12}$ To ensure comparability across countries, the data are based on a case study of a hypothetical representative firm examined across countries and a range of assumptions were made in the calculation. ${ }^{13}$ Given that the

\footnotetext{
${ }^{12}$ The first Doing Business report, published in 2003, covered 133 economies.

${ }^{13}$ Details are available at $h t t p: / / w w w . d o i n g b u s i n e s s . o r g / a b o u t-u s$.
} 
data for our measure of tax complexity is only available from 2006 and onward, we restrict our working sample to the period between 2006 and 2009 for the tax complexity analysis.

For robustness checks, we also employ alternative measures for both tax mix and tax complexity. First, given that certain types of property taxes can be treated as direct taxes, such as ordinary real estate property tax imposed on the person owning the property (which may also be adjusted for the personal characteristics of owners), and because we are not able to distinguish among different types within the data we have, we therefore alternatively define it as part of direct taxes to create another tax mix variable. Second, since the fiscal illusion hypothesis held that tax rates not tax bills would dominate taxpayers' perception of tax burden, we use top (the highest bracket) statutory tax rate on personal income as a proxy to alternatively test Hypothesis 1, and expect that the higher the top statutory personal income tax rate, the less will be the underestimation of actual tax burden and so the less corruption in the country. The data for top statutory personal income tax rate are derived from the World Tax Indicators from the International Center for Public Policy at Georgia State University, which compiled the data from a combination of multiple sources. ${ }^{14}$ Third, along similar lines, we employ another indicator from the World Bank Doing Business Survey to measure tax complexity - the number of payments that a representative firm has to make. This indicator reflects the total number of taxes and contributions to be paid, the method and frequency of payment, and the number of agencies involved.

Before we turn to discuss our empirical results more rigorously in the next section, let us first take a look at the simple relationship between tax structure and corruption by presenting simple scatter plots of corruption against tax structure. As shown in Figure 1, regardless the three measures of corruption, corruption is negatively associated with the tax mix between direct and indirect taxes, which provides a preliminary evidence for Hypothesis 1 that a higher reliance on direct taxes contributes to a lower level of corruption in the country. By contrast, Figure 2 clearly indicates a positive relationship between corruption

\footnotetext{
${ }^{14}$ The data for top statutory personal income tax rates are only available up to 2005, so our working sample is from 1995 to 2005 when this variable enters the specifications.
} 
and tax complexity, supporting Hypothesis 2 that the more complex the tax system, the higher the corruption will be in the country.

\section{Empirical Results}

In this section we present our main results for equation (1) based on both OLS and 2SLS estimation approaches, along with several robustness checks. The F-test statistics from the first stage regression and the over-identifying restriction tests are noted at the bottom of each table for 2SLS estimation results. As shown, the F-statistics are reasonably large and statistically significant, indicating the instruments are good predictors of our tax structure variables; the p-values of the Hansen J statistics suggest that we cannot reject the hypothesis of no correlation between the instruments and the error term in the regressions.

\subsection{Main Results}

Table 2 reports the results from OLS estimation for tax structure measured as the mix of direct versus indirect taxes. We experiment with various specifications: in columns (1) and (2) we use the baseline specifications with government structure being captured by federalism and the degree of fiscal decentralization alternatively; in columns (3) and (4) we add additional economic and socio-demographic factors to the specifications, and in columns (5) and (6) we augment it with a series of other political and cultural factors. Throughout all six regressions, we find a negative and statistically significant coefficient for the tax mix variable in line with Hypothesis 1 that countries relying more heavily on direct taxes tend to have a lower level of corruption. The magnitudes of the coefficients are very close across different specifications, around -0.07 , implying that a one standard deviation increase in tax mix will be associated with a reduction in the country's corruption rating of around 24 percent of a standard deviation. Table 3 reports the corresponding results from OLS estimation for the case that tax structure is defined in terms of its level of complexity. Consistent with 
Hypothesis 2, the results provide clear evidence that an increase in the complexity of the tax system (i.e. the time spent on complying with tax requirements) is associated with an increase in the corruption level of the country. In magnitude, a one standard deviation increase in our complexity measure will be associated with an increment of the country's corruption rating of around 41 percent of a standard deviation. It should be noted that regardless how government structure is measured, either federalism or decentralization, it does not change the results of our key variables of interest. However, given a large missing data of the decentralization index, it significantly reduces our working sample size when this variable is included. For this reason, we focus on the specifications adding federalism as measurement of government structure in the subsequent analysis.

Table 4 documents the results by utilizing the instrumental method to deal with the endogeneity issue of tax structure. Results are similar to those in Tables 2 and 3, except that the magnitudes of the effects are now larger - roughly three times as large as the corresponding OLS results for tax mix variable and about one and a half times as large as the corresponding OLS results for tax complexity variable.

For the control variables with statistically significant coefficients, the results are mostly consistent with those obtained in the previous literature. Income level is negatively correlated with corruption, implying an effective role of economic development in combating corruption. Democracy plays a positive role in reducing corruption, confirming a result that has received well recognition in both academic and policy circles. Internet has a negative and significant coefficient, supporting the argument that Internet is a useful technology for controlling corruption. A higher female labor participation leads to less corruption - a result reflecting various characteristics of women. Both inflation and human capital are positively associated with corruption, but they are only statistically significant at the margin. Despite their potential roles in determining corruption, other variables are generally found to be statistically insignificant in our empirical analysis. 


\subsection{Robustness}

In order to test for the robustness of the main results, we conduct sensitivity analysis along two dimensions. First, we employ two alternative measures of corruption from WGI and ICRG that have been equally used in the previous literature. As noted earlier, our principal measure of corruption is perception-based and may suffer from some bias; the use of alternative corruption indices helps check whether our results are robust across different methods in measuring corruption. Second, as discussed in subsection 3.3, we employ two alternative measures of tax structure for testing Hypothesis 1 (i.e. defining property taxes as part of direct taxes in calculating tax mix and the top statutory personal income tax rate) and an additional measure for tax complexity (i.e. the number of payments that a representative firm has to make in order to meet tax obligations).

Tables 5 and 6 summarize the corresponding robustness results, respectively. To save space, we only present results from 2SLS estimations for both the baseline specifications and specifications with full set of control variables. ${ }^{15}$ As shown in Table 5, the results with alternative measures of corruption are highly consistent and robust with our main results. They confirm the existence of a negative (positive) and significant correlation between tax mix (tax complexity) and corruption, though the estimated effects of tax structure are slightly smaller in magnitude than our previous ones. Similarly, Table 6 provides additional robustness results for the case with alternative definitions of tax structure. It is noteworthy to mention that even if we test Hypothesis 1 by using top statutory personal income tax rate, it provides an expected result that a higher level of personal income tax rate leads to a reduction of corruption, as the higher the statutory tax rate, the less will be the underestimation of actual tax burden. Alternative measures of tax mix and tax complexity provide consistent results with our main ones.

\footnotetext{
${ }^{15}$ The 2SLS estimation is deem as a more suitable approach for its correction for the potential endogeneity problem.
} 


\section{Conclusion}

This paper adds to the literature discussing the determinants of corruption by providing a novel factor that has never been examined before - tax structure. The theoretical hypotheses are derived from the traditional wisdom of fiscal illusion, which claims that tax burden is less visible for indirect taxes versus direct taxes, and for more complex tax systems versus less complex tax systems. Following these observations, we further argue that greater reliance on indirect taxes and/or having a more complex tax system may lead to greater government expenditure and less supervision on government operations from the taxpayers, which are directly correlated with corruption. Our hypotheses are then tested by employing a large sample of countries over the years 1995-2009. It is confirmed with the data that countries relying more heavily on direct taxes tend to enjoy a lower level of corruption, and countries with more complex tax systems tend to have a higher level of corruption. These results are also shown to be robust across different regression methods, alternative measures of corruption and tax structure.

From a policy perspective, it is important to note that the optimal choice of tax structure, especially the mix between direct taxes and indirect taxes, usually involves the discussion of its impacts on the key aspects of the economy - mainly economic growth and income distribution. Our result suggests that besides this traditional consideration, it is also critical to keep in mind that the optimal choice of taxation also matters for other aspects of the society, for example, corruption. Therefore, systematic evaluation of the current tax structure requires incorporating all its possible impacts into consideration, and further tax reforms should be built on the knowledge - both positive and negative - that we have learned. 


\section{References}

Alesina, A., and Angeletos, G.-M. (2005). "Corruption, inequality, and fairness." Journal of Monetary Economics, 52(7), 1227-1244.

Alesina, A., and Wacziarg, R. (1998). "Openness, country size and government." Journal of Public Economics, $69(3), 305$ - 321.

Ali, A. M., and Isse, H. S. (2003). "Determinants of economic corruption: A cross-country comparison." Cato Journal, 22(3), 449-466.

Alon, A., and Hageman, A. (2012). "The impact of corruption on firm tax compliance in transition economies: Whom do you trust?" Journal of Business Ethics, 1-16.

Andersen, T. B., Bentzen, J., Dalgaard, C.-J., and Selaya, P. (2011). "Does the Internet reduce corruption? Evidence from U.S. states and across countries." World Bank Economic Review, 25(3), 387-417.

Baker, S. H. (1983). "The determinants of median voter tax liability: An empirical test of the fiscal illusion hypothesis." Public Finance Review, 11(1), 95-108.

Barreto, R. A., and Alm, J. (2003). "Corruption, optimal taxation, and growth." Public Finance Review, 31(3), 207-240.

Braun, M., and Di Tella, R. (2004). "Inflation, inflation variability, and corruption." Economics and Politics, 16(1), 77-100.

Broadman, H. G., and Recanatini, F. (2001). "Seeds of corruption: Do market institutions matter?" MOST: Economic Policy in Transitional Economies, 11(4), 359-392.

Brunetti, A., and Weder, B. (2003). "A free press is bad news for corruption." Journal of Public Economics, 87(7-8), 1801-1824.

Buchanan, J. M. (1967). Public Finance in Democratic Process. Chapel Hill: University of North Carolina Press.

Buchanan, J. M., and Wagner, R. E. (1978). "Dialogues concerning fiscal religion." Journal of Monetary Economics, 4(3), 627-636.

Chand, S. K., and Moene, K. O. (1999). "Controlling fiscal corruption." World Development, $27(7), 1129-1140$.

Chang, E. C., and Golden, M. A. (2007). "Electoral systems, district magnitude and corruption." British Journal of Political Science, 37, 115-137.

Craig, E., and Heins, A. (1980). "The effect of tax elasticity on government spending." Public Choice, 35(3), 267-275.

Damania, R., Fredriksson, P., and Mani, M. (2004). "The persistence of corruption and regulatory compliance failures: Theory and evidence." Public Choice, 121 (3), 363-390. 
Dollery, B., and Worthingtong, A. (1999). "Fiscal illusion at the local level: An empirical test using australian municipal data." Economic Record, 75(1), 37-48.

Dollery, B. E., and Worthington, A. C. (1996). "The empirical analysis of fiscal illusion." Journal of Economic Surveys, 10(3), 261-297.

Downs, A. (1957). "An economic theory of political action in a democracy." Journal of Political Economy, 65, 135.

Escaleras, M., Lin, S., and Register, C. (2010). "Freedom of information acts and public sector corruption." Public Choice, 145(3), 435-460.

Fisman, R., and Gatti, R. (2002). "Decentralization and corruption: Evidence across countries." Journal of Public Economics, 83(3), 325 - 345.

Goel, R., and Nelson, M. (2011). "Government fragmentation versus fiscal decentralization and corruption." Public Choice, 148(3), 471-490.

Goel, R. K., and Nelson, M. A. (1998). "Corruption and government size: A disaggregated analysis." Public Choice, 97(1/2), pp. 107-120.

Goel, R. K., Nelson, M. A., and Naretta, M. A. (2012). "The Internet as an indicator of corruption awareness." European Journal of Political Economy, 28(1), 64 - 75.

Gunardi, H. S. (2008). Courruption and Governance aournd the World: An Empirical Investigation. PPI Publishers, Enschede, The Netherlands.

Gurgur, T., and Shah, A. (2008). "Localization and corruption: Panacea or pandora's box?" CEMA Working Papers 581, China Economics and Management Academy, Central University of Finance and Economics.

Heyndels, B., and Smolders, C. (1995). "Tax complexity and fiscal illusion." Public Choice, $85(1-2), 127-141$.

Knack, S., and Azfar, O. (2003). "Trade intensity, country size and corruption." Economics of Governance, 4(1), 1-18.

Kotera, G., Okada, K., and Samreth, S. (2012). "Government size, democracy, and corruption: An empirical investigation." Economic Modelling, 29(6), 2340 - 2348.

Kunicová, J., and Rose-Ackerman, S. (2005). "Electoral rules and constitutional structures as constraints on corruption." British Journal of Political Science, 35, 573-606.

La Porta, R., Lopez-de Silanes, F., Shleifer, A., and Vishny, R. (1999). "The quality of government." Journal of Law, Economics, and Organization, 15(1), 222-279.

Lederman, D., Loayza, N. V., and Soares, R. R. (2005). "Accountability and corruption: Political institutions matter." Economics \&f Politics, 17(1), 1-35. 
Lee, Y., and Gordon, R. H. (2005). "Tax structure and economic growth." Journal of Public Economics, 89(5-6), 1027-1043.

Mauro, P. (1995). "Corruption and growth." The Quarterly Journal of Economics, 110(3), $681-712$.

Mill, J. S. (1848). Principles of Political Economy. Oxford: Oxford University Press.

Misiolek, W., and Elder, H. (1988). "Tax structure and the size of government: An empirical analysis of the fiscal illusion and fiscal stress arguments." Public Choice, 57(3), 233-245.

Paldam, M. (2002). "The cross-country pattern of corruption: Economics, culture and the seesaw dynamics." European Journal of Political Economy, 18(2), 215-240.

Pani, M. (2011). "Hold your nose and vote: corruption and public decisions in a representative democracy." Public Choice, 148(1), 163-196.

Pommerehne, W. W., and Schneider, F. (1978). "Fiscal illusion, political institutions, and local public spending." Kyklos, 31(3), 381-408.

Seldadyo, H., and de Haan, J. (2006). "The determinants of corruption literature: Survey and new evidence." the 2006 EPCS Conference, Turku, Finland, 20-23.

Swamy, A., Knack, S., Lee, Y., and Azfar, O. (2001). "Gender and corruption." Journal of Development Economics, 64 (1), 25-55.

Tavares, J. (2003). "Does foreign aid corrupt?" Economics Letters, 79(1), 99-106.

Thornton, J. (2008). "Corruption and the composition of tax revenue in Middle East and African economies." South African Journal of Economics, 76(2), 316-320.

Treisman, D. (2000). "The causes of corruption: A cross-national study." Journal of Public Economics, $76(3)$, 399-457.

Wagner, R. (1976). "Revenue structure, fiscal illusion, and budgetary choice." Public Choice, $25(1), 45-61$. 

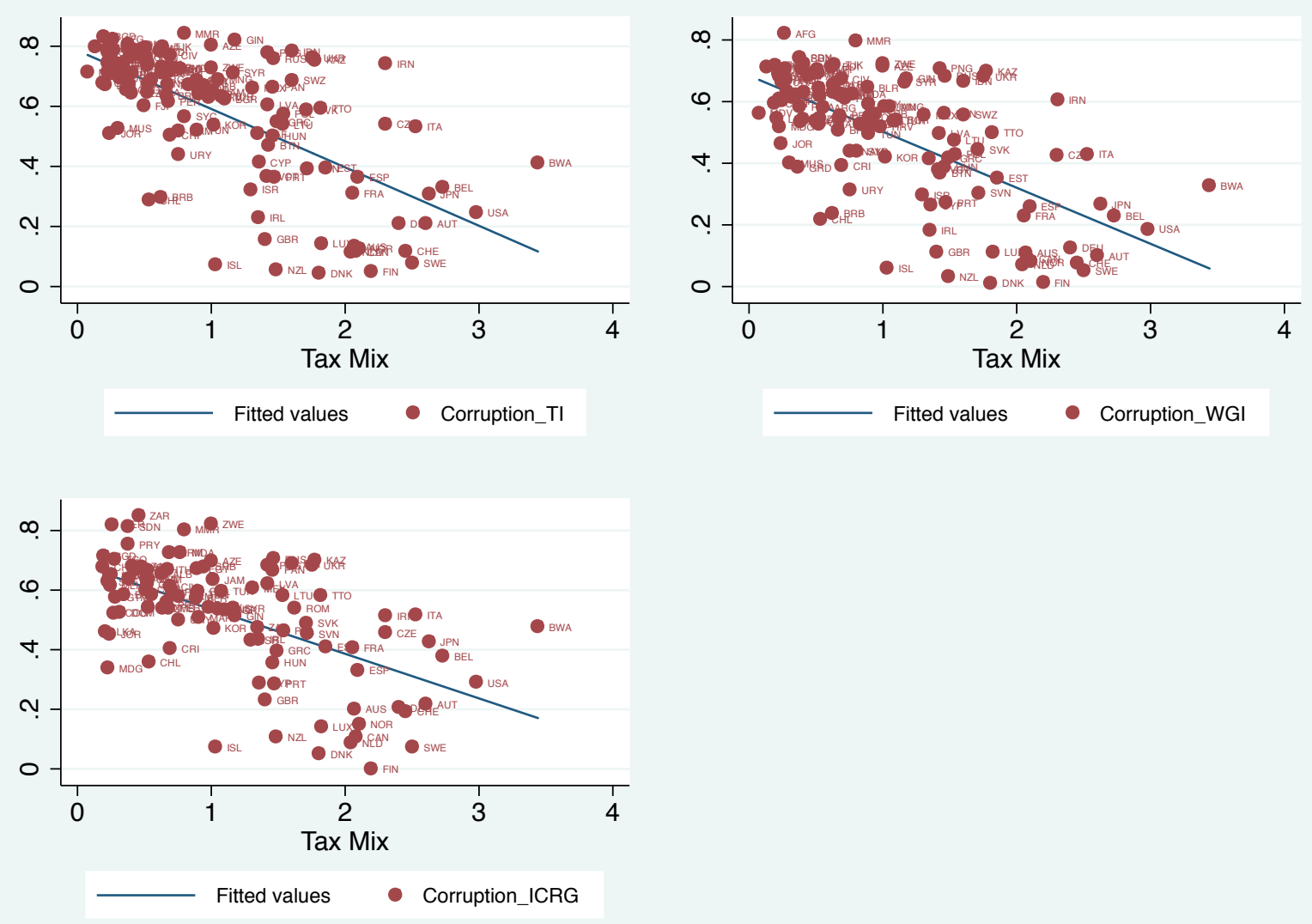

Figure 1: Scatter Plot of Corruption and Tax Mix 


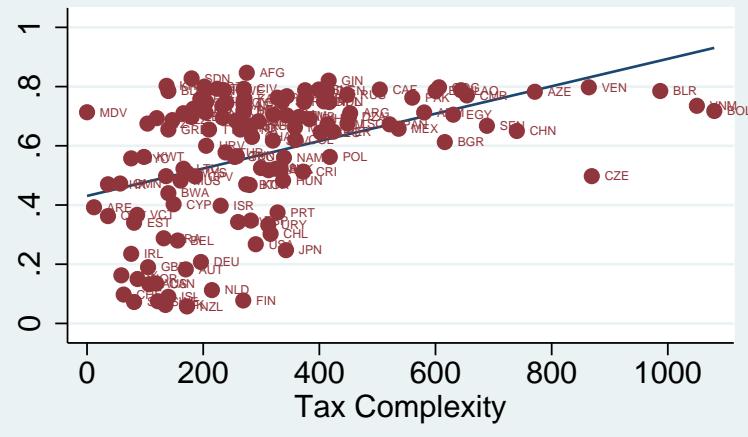

Fitted values

- Corruption_TI

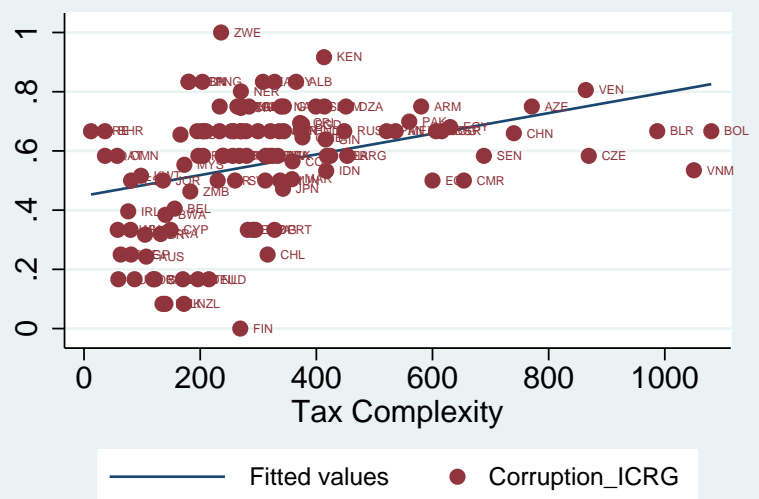

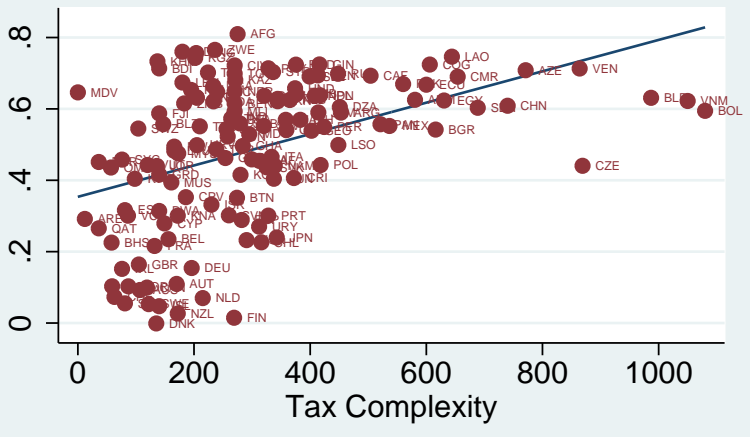

Fitted values

- Corruption_WGI

Figure 2: Scatter Plot of Corruption and Tax Complexity 
Table 1: Summary Statistics, Cross-Country Data

\begin{tabular}{lccccc}
\hline \hline \multicolumn{1}{c}{ Variable } & Obs. & Mean & Std. Dev. & Min. & Max. \\
\hline Corruption, TI index & 141 & 0.575 & 0.214 & 0.044 & 0.841 \\
Corruption, WGI index & 143 & 0.485 & 0.201 & 0.010 & 0.820 \\
Corruption, ICRG index & 120 & 0.511 & 0.186 & 0 & 0.848 \\
Tax mix (primary) & 127 & 1.065 & 0.735 & 0.075 & 3.441 \\
Tax mix (alternative) & 127 & 1.305 & 1.073 & 0.087 & 6.505 \\
PITRate & 141 & 33.096 & 13.725 & 0 & 60 \\
Ln tax time requirement & 141 & 5.490 & 0.715 & 2.485 & 6.985 \\
Ln tax payments & 141 & 3.204 & 0.742 & 1.099 & 4.317 \\
Ln GDP & 147 & 23.678 & 2.211 & 19.371 & 29.948 \\
Ln population density & 149 & 4.267 & 1.485 & 0.459 & 9.717 \\
Openness & 148 & 0.471 & 0.257 & 0.008 & 1.914 \\
Democracy & 145 & 0.629 & 0.305 & 0 & 1 \\
Government size & 145 & 0.096 & 0.045 & 0.033 & 0.262 \\
Ln Internet & 146 & 1.953 & 1.504 & -2.350 & 4.119 \\
Federal dummy & 142 & 0.120 & 0.326 & 0 & 1 \\
Decentralization & 82 & 0.211 & 0.159 & 0.007 & 0.777 \\
Inflation & 146 & 0.247 & 1.718 & -0.033 & 20.730 \\
Human capital & 129 & 7.545 & 2.665 & 1.258 & 12.751 \\
Female labor participation & 141 & 0.520 & 0.157 & 0.125 & 0.873 \\
Legal origin & 150 & 0.293 & 0.457 & 0 & 1 \\
Colonial dummy & 144 & 0.285 & 0.453 & 0 & 1 \\
Ethnic fractionalization & 126 & 0.457 & 0.250 & 0.004 & 1 \\
\hline
\end{tabular}

Notes: All values are averages over 1995-2009; all corruption indices are rescaled to take values between 0 and 1 with $0=$ least corruption. 
Table 2: Tax Mix and Corruption: OLS Regressions

\begin{tabular}{|c|c|c|c|c|c|c|}
\hline & (1) & $(2)$ & (3) & (4) & $(5)$ & (6) \\
\hline Tax mix (primary) & $\begin{array}{c}-0.073^{* * *} \\
(-3.55)\end{array}$ & $\begin{array}{c}-0.049^{*} \\
(-1.66)\end{array}$ & $\begin{array}{c}-0.072^{* * *} \\
(-3.51)\end{array}$ & $\begin{array}{c}-0.062^{* *} \\
(-2.03)\end{array}$ & $\begin{array}{c}-0.073^{* * *} \\
(-3.42)\end{array}$ & $\begin{array}{c}-0.061^{*} \\
(-1.83)\end{array}$ \\
\hline Ln GDP & $\begin{array}{l}0.005 \\
(0.45)\end{array}$ & $\begin{array}{l}-0.003 \\
(-0.22)\end{array}$ & $\begin{array}{l}0.003 \\
(0.26)\end{array}$ & $\begin{array}{l}-0.002 \\
(-0.13)\end{array}$ & $\begin{array}{l}0.007 \\
(0.65)\end{array}$ & $\begin{array}{l}0.004 \\
(0.20)\end{array}$ \\
\hline Ln population density & $\begin{array}{l}0.009 \\
(0.87)\end{array}$ & $\begin{array}{c}0.024^{*} \\
(1.70)\end{array}$ & $\begin{array}{l}0.010 \\
(1.01)\end{array}$ & $\begin{array}{c}0.031^{* *} \\
(2.54)\end{array}$ & $\begin{array}{l}0.015 \\
(1.41)\end{array}$ & $\begin{array}{c}0.029^{* *} \\
(2.05)\end{array}$ \\
\hline Openness & $\begin{array}{l}0.076 \\
(0.81)\end{array}$ & $\begin{array}{l}-0.138 \\
(-1.48)\end{array}$ & $\begin{array}{l}0.024 \\
(0.25)\end{array}$ & $\begin{array}{l}-0.145 \\
(-1.52)\end{array}$ & $\begin{array}{l}0.036 \\
(0.35)\end{array}$ & $\begin{array}{l}-0.125 \\
(-1.09)\end{array}$ \\
\hline Democracy & $\begin{array}{c}-0.244^{* * *} \\
(-5.49)\end{array}$ & $\begin{array}{c}-0.274^{* * * *} \\
(-3.23)\end{array}$ & $\begin{array}{c}-0.203^{* * *} \\
(-4.32)\end{array}$ & $\begin{array}{l}-0.082 \\
(-0.88)\end{array}$ & $\begin{array}{c}-0.168 * * * \\
(-3.50)\end{array}$ & $\begin{array}{l}-0.055 \\
(-0.58)\end{array}$ \\
\hline Government size & $\begin{array}{l}0.015 \\
(0.06)\end{array}$ & $\begin{array}{c}1.131^{* *} \\
(2.05)\end{array}$ & $\begin{array}{l}0.259 \\
(0.84)\end{array}$ & $\begin{array}{l}0.608 \\
(1.09)\end{array}$ & $\begin{array}{l}0.465 \\
(1.26)\end{array}$ & $\begin{array}{l}0.615 \\
(1.11)\end{array}$ \\
\hline Ln Internet & $\begin{array}{c}-0.063^{* * *} \\
(-4.19)\end{array}$ & $\begin{array}{c}-0.088 * * * \\
(-2.83)\end{array}$ & $\begin{array}{c}-0.093^{* * *} \\
(-4.67)\end{array}$ & $\begin{array}{c}-0.163^{* * *} \\
(-5.52)\end{array}$ & $\begin{array}{c}-0.098^{* * * *} \\
(-5.08)\end{array}$ & $\begin{array}{c}-0.169^{* * *} \\
(-5.77)\end{array}$ \\
\hline Federal dummy & $\begin{array}{l}0.031 \\
(0.70)\end{array}$ & & $\begin{array}{l}0.030 \\
(0.71)\end{array}$ & & $\begin{array}{l}0.025 \\
(0.61)\end{array}$ & \\
\hline Decentralization & & $\begin{array}{l}-0.179 \\
(-1.23)\end{array}$ & & $\begin{array}{l}0.029 \\
(0.22)\end{array}$ & & $\begin{array}{l}-0.084 \\
(-0.62)\end{array}$ \\
\hline Inflation & & & $\begin{array}{l}0.003 \\
(1.16)\end{array}$ & $\begin{array}{c}0.207^{* *} \\
(2.19)\end{array}$ & $\begin{array}{l}0.005 \\
(1.46)\end{array}$ & $\begin{array}{l}0.151 \\
(1.63)\end{array}$ \\
\hline Human capital & & & $\begin{array}{l}0.014 \\
(1.63)\end{array}$ & $\begin{array}{l}0.012 \\
(1.05)\end{array}$ & $\begin{array}{c}0.018^{* *} \\
(2.23)\end{array}$ & $\begin{array}{l}0.018 \\
(1.54)\end{array}$ \\
\hline Female labor participatio & & & $\begin{array}{c}-0.191^{* *} \\
(-2.23)\end{array}$ & $\begin{array}{l}-0.189 \\
(-1.17)\end{array}$ & $\begin{array}{c}-0.166^{*} \\
(-1.89)\end{array}$ & $\begin{array}{l}-0.139 \\
(-0.80)\end{array}$ \\
\hline Legal origin & & & & & $\begin{array}{c}-0.091^{*} \\
(-1.95)\end{array}$ & $\begin{array}{l}-0.086 \\
(-1.54)\end{array}$ \\
\hline Colonial dummy & & & & & $\begin{array}{l}0.021 \\
(0.42)\end{array}$ & $\begin{array}{l}-0.017 \\
(-0.22)\end{array}$ \\
\hline Ethnic fractionalization & & & & & $\begin{array}{l}0.113^{*} \\
(1.95)\end{array}$ & $\begin{array}{l}0.093 \\
(1.36)\end{array}$ \\
\hline Constant & $\begin{array}{c}0.738^{* *} \\
(2.60)\end{array}$ & $\begin{array}{c}1.002^{* * *} \\
(2.75)\end{array}$ & $\begin{array}{c}0.813^{* * *} \\
(2.92)\end{array}$ & $\begin{array}{c}0.988^{* *} \\
(2.54)\end{array}$ & $\begin{array}{l}0.579^{*} \\
(1.97)\end{array}$ & $\begin{array}{l}0.774 \\
(1.56)\end{array}$ \\
\hline Observations & 118 & 73 & 106 & 67 & 105 & 67 \\
\hline R-squared & 0.695 & 0.729 & 0.732 & 0.796 & 0.761 & 0.822 \\
\hline
\end{tabular}

Notes: Time period is 1995-2009. Robust t-statistics in parentheses. ${ }^{* * *},{ }^{* *},{ }^{*}$ denote significance at the 1,5 , and $10 \%$ level, respectively. 
Table 3: Tax Complexity and Corruption: OLS Regressions

\begin{tabular}{|c|c|c|c|c|c|c|}
\hline & (1) & (2) & (3) & (4) & $(5)$ & (6) \\
\hline Ln tax time requirement & $\begin{array}{c}0.116^{* * *} \\
(9.38)\end{array}$ & $\begin{array}{c}0.130^{* * *} \\
(6.46)\end{array}$ & $\begin{array}{c}0.126^{* * *} \\
(10.65)\end{array}$ & $\begin{array}{c}0.141^{* * *} \\
(5.90)\end{array}$ & $\begin{array}{c}0.122^{* * *} \\
(9.79)\end{array}$ & $\begin{array}{c}0.120^{* * *} \\
(4.59)\end{array}$ \\
\hline Ln GDP & $\begin{array}{c}-0.032^{* * *} \\
(-4.20)\end{array}$ & $\begin{array}{l}-0.009 \\
(-0.81)\end{array}$ & $\begin{array}{c}-0.033^{* * *} \\
(-4.41)\end{array}$ & $\begin{array}{l}-0.010 \\
(-0.74)\end{array}$ & $\begin{array}{c}-0.031^{* * *} \\
(-3.71)\end{array}$ & $\begin{array}{l}-0.006 \\
(-0.34)\end{array}$ \\
\hline Ln population density & $\begin{array}{l}0.015^{*} \\
(1.71)\end{array}$ & $\begin{array}{l}0.006 \\
(0.49)\end{array}$ & $\begin{array}{l}0.011 \\
(1.23)\end{array}$ & $\begin{array}{l}0.005 \\
(0.44)\end{array}$ & $\begin{array}{l}0.013 \\
(1.37)\end{array}$ & $\begin{array}{l}0.011 \\
(0.83)\end{array}$ \\
\hline Openness & $\begin{array}{l}-0.093 \\
(-1.42)\end{array}$ & $\begin{array}{l}0.010 \\
(0.12)\end{array}$ & $\begin{array}{c}-0.097^{*} \\
(-1.67)\end{array}$ & $\begin{array}{l}0.010 \\
(0.11)\end{array}$ & $\begin{array}{l}-0.093 \\
(-1.53)\end{array}$ & $\begin{array}{l}-0.009 \\
(-0.09)\end{array}$ \\
\hline Democracy & $\begin{array}{c}-0.254^{* * *} \\
(-7.95)\end{array}$ & $\begin{array}{c}-0.254^{* * *} \\
(-3.62)\end{array}$ & $\begin{array}{c}-0.210^{* * *} \\
(-5.47)\end{array}$ & $\begin{array}{l}-0.152 \\
(-1.59)\end{array}$ & $\begin{array}{c}-0.202^{* * *} \\
(-5.13)\end{array}$ & $\begin{array}{l}-0.098 \\
(-1.01)\end{array}$ \\
\hline Government size & $\begin{array}{l}-0.052 \\
(-0.21)\end{array}$ & $\begin{array}{l}0.240 \\
(0.57)\end{array}$ & $\begin{array}{l}0.149 \\
(0.71)\end{array}$ & $\begin{array}{l}-0.213 \\
(-0.44)\end{array}$ & $\begin{array}{l}0.219 \\
(0.97)\end{array}$ & $\begin{array}{l}-0.116 \\
(-0.23)\end{array}$ \\
\hline Ln Internet & $\begin{array}{c}-0.041^{* * *} \\
(-3.77)\end{array}$ & $\begin{array}{c}-0.083^{* * *} \\
(-3.37)\end{array}$ & $\begin{array}{c}-0.060^{* * *} \\
(-4.04)\end{array}$ & $\begin{array}{c}-0.078^{* *} \\
(-2.20)\end{array}$ & $\begin{array}{c}-0.062^{* * *} \\
(-3.89)\end{array}$ & $\begin{array}{c}-0.109^{* * *} \\
(-2.96)\end{array}$ \\
\hline Federal dummy & $\begin{array}{l}0.039 \\
(1.18)\end{array}$ & & $\begin{array}{l}0.025 \\
(0.69)\end{array}$ & & $\begin{array}{l}0.016 \\
(0.42)\end{array}$ & \\
\hline Decentralization & & $\begin{array}{c}-0.188^{*} \\
(-2.00)\end{array}$ & & $\begin{array}{l}-0.089 \\
(-0.66)\end{array}$ & & $\begin{array}{l}-0.169 \\
(-1.10)\end{array}$ \\
\hline Inflation & & & $\begin{array}{c}0.001^{* *} \\
(2.15)\end{array}$ & $\begin{array}{l}1.035 \\
(1.57)\end{array}$ & $\begin{array}{c}0.001^{* *} \\
(2.09)\end{array}$ & $\begin{array}{l}0.975 \\
(1.26)\end{array}$ \\
\hline Human capital & & & $\begin{array}{l}0.003 \\
(0.50)\end{array}$ & $\begin{array}{l}-0.002 \\
(-0.16)\end{array}$ & $\begin{array}{l}0.006 \\
(0.87)\end{array}$ & $\begin{array}{l}0.000 \\
(0.02)\end{array}$ \\
\hline Female labor participation & & & $\begin{array}{c}-0.250^{* * *} \\
(-3.50)\end{array}$ & $\begin{array}{l}-0.211 \\
(-1.17)\end{array}$ & $\begin{array}{c}-0.252^{* * *} \\
(-3.41)\end{array}$ & $\begin{array}{l}-0.161 \\
(-0.87)\end{array}$ \\
\hline Legal origin & & & & & $\begin{array}{l}-0.014 \\
(-0.39)\end{array}$ & $\begin{array}{l}-0.036 \\
(-0.88)\end{array}$ \\
\hline Colonial dummy & & & & & $\begin{array}{l}-0.005 \\
(-0.12)\end{array}$ & $\begin{array}{l}-0.075 \\
(-1.27)\end{array}$ \\
\hline Ethnic fractionalization & & & & & $\begin{array}{l}0.075 \\
(1.62)\end{array}$ & $\begin{array}{l}0.093 \\
(1.08)\end{array}$ \\
\hline Constant & $\begin{array}{c}0.966^{* * *} \\
(4.77)\end{array}$ & $\begin{array}{l}0.456 \\
(1.48)\end{array}$ & $\begin{array}{c}1.076^{* * *} \\
(5.61)\end{array}$ & $\begin{array}{l}0.405 \\
(0.99)\end{array}$ & $\begin{array}{c}0.968^{* * *} \\
(4.29)\end{array}$ & $\begin{array}{l}0.422 \\
(0.90)\end{array}$ \\
\hline Observations & 128 & 64 & 110 & 56 & 110 & 56 \\
\hline R-squared & 0.754 & 0.810 & 0.808 & 0.823 & 0.813 & 0.841 \\
\hline
\end{tabular}

Notes: Since the data for tax complexity is only available from year 2006 and onward, the working time period is 2006-2009. Robust t-statistics in parentheses. ${ }^{* * *},{ }^{* *},{ }^{*}$ denote significance at the 1,5 , and $10 \%$ level, respectively. 
Table 4: Tax Structure and Corruption: 2SLS Regressions

\begin{tabular}{|c|c|c|c|c|c|c|}
\hline & \multicolumn{3}{|c|}{ Tax Mix } & \multicolumn{3}{|c|}{ Tax Complexity } \\
\hline & $(1)$ & $(2)$ & $(3)$ & $(4)$ & $(5)$ & $(6)$ \\
\hline Tax mix (primary) & $\begin{array}{c}-0.153^{* * *} \\
(-2.93)\end{array}$ & $\begin{array}{c}-0.227^{* * *} \\
(-3.89)\end{array}$ & $\begin{array}{c}-0.233^{* * *} \\
(-3.98)\end{array}$ & & & \\
\hline Ln tax time requirement & & & & $\begin{array}{c}0.135^{* * *} \\
(6.91)\end{array}$ & $\begin{array}{c}0.178^{* * *} \\
(5.15)\end{array}$ & $\begin{array}{c}0.180^{* * *} \\
(5.19)\end{array}$ \\
\hline Ln GDP & $\begin{array}{l}0.006 \\
(0.42)\end{array}$ & $\begin{array}{c}0.011 \\
(0.68)\end{array}$ & $\begin{array}{c}0.017 \\
(1.00)\end{array}$ & $\begin{array}{c}-0.028^{* * *} \\
(-3.50)\end{array}$ & $\begin{array}{c}-0.031^{* * *} \\
(-3.95)\end{array}$ & $\begin{array}{c}-0.032^{* * *} \\
(-3.80)\end{array}$ \\
\hline Ln population density & $\begin{array}{l}-0.008 \\
(-0.65)\end{array}$ & $\begin{array}{l}0.000 \\
(0.02)\end{array}$ & $\begin{array}{l}0.004 \\
(0.26)\end{array}$ & $\begin{array}{l}-0.001 \\
(-0.11)\end{array}$ & $\begin{array}{l}-0.004 \\
(-0.43)\end{array}$ & $\begin{array}{l}-0.003 \\
(-0.25)\end{array}$ \\
\hline Openness & $\begin{array}{l}0.083 \\
(0.74)\end{array}$ & $\begin{array}{l}-0.025 \\
(-0.22)\end{array}$ & $\begin{array}{l}-0.029 \\
(-0.24)\end{array}$ & $\begin{array}{l}-0.067 \\
(-1.22)\end{array}$ & $\begin{array}{l}-0.053 \\
(-0.96)\end{array}$ & $\begin{array}{l}-0.059 \\
(-1.06)\end{array}$ \\
\hline Democracy & $\begin{array}{c}-0.182^{* * *} \\
(-3.18)\end{array}$ & $\begin{array}{l}-0.108 \\
(-1.57)\end{array}$ & $\begin{array}{l}-0.076 \\
(-1.11)\end{array}$ & $\begin{array}{c}-0.239^{* * *} \\
(-7.12)\end{array}$ & $\begin{array}{c}-0.193^{* * *} \\
(-4.70)\end{array}$ & $\begin{array}{c}-0.196^{* * *} \\
(-4.87)\end{array}$ \\
\hline Government size & $\begin{array}{l}0.080 \\
(0.26)\end{array}$ & $\begin{array}{l}0.388 \\
(0.97)\end{array}$ & $\begin{array}{l}0.466 \\
(1.15)\end{array}$ & $\begin{array}{l}-0.026 \\
(-0.10)\end{array}$ & $\begin{array}{l}0.341 \\
(1.62)\end{array}$ & $\begin{array}{l}0.380 \\
(1.64)\end{array}$ \\
\hline Ln Internet & $\begin{array}{c}-0.043^{* *} \\
(-2.49)\end{array}$ & $\begin{array}{c}-0.086^{* * *} \\
(-3.68)\end{array}$ & $\begin{array}{c}-0.095^{* * *} \\
(-3.85)\end{array}$ & $\begin{array}{c}-0.041^{* * *} \\
(-3.56)\end{array}$ & $\begin{array}{c}-0.050^{* * *} \\
(-3.11)\end{array}$ & $\begin{array}{c}-0.045^{* *} \\
(-2.53)\end{array}$ \\
\hline Federal dummy & $\begin{array}{l}0.056 \\
(1.30)\end{array}$ & $\begin{array}{l}0.052 \\
(1.22)\end{array}$ & $\begin{array}{l}0.037 \\
(0.90)\end{array}$ & $\begin{array}{l}0.039 \\
(1.23)\end{array}$ & $\begin{array}{l}0.023 \\
(0.74)\end{array}$ & $\begin{array}{l}0.014 \\
(0.44)\end{array}$ \\
\hline Inflation & & $\begin{array}{l}0.004 \\
(1.04)\end{array}$ & $\begin{array}{l}0.007 \\
(1.46)\end{array}$ & & $\begin{array}{l}0.000 \\
(1.09)\end{array}$ & $\begin{array}{l}0.000 \\
(0.72)\end{array}$ \\
\hline Human capital & & $\begin{array}{c}0.037^{* * *} \\
(3.10)\end{array}$ & $\begin{array}{c}0.040^{* * *} \\
(3.20)\end{array}$ & & $\begin{array}{l}0.003 \\
(0.43)\end{array}$ & $\begin{array}{l}0.004 \\
(0.59)\end{array}$ \\
\hline Female labor participation & & $\begin{array}{l}-0.167 \\
(-1.42)\end{array}$ & $\begin{array}{l}-0.169 \\
(-1.42)\end{array}$ & & $\begin{array}{c}-0.184^{* * *} \\
(-2.62)\end{array}$ & $\begin{array}{c}-0.200^{* * *} \\
(-2.78)\end{array}$ \\
\hline Legal origin & & & $\begin{array}{l}-0.043 \\
(-0.59)\end{array}$ & & & $\begin{array}{l}0.031 \\
(0.95)\end{array}$ \\
\hline Colonial dummy & & & $\begin{array}{l}-0.027 \\
(-0.33)\end{array}$ & & & $\begin{array}{l}-0.017 \\
(-0.50)\end{array}$ \\
\hline Ethnic fractionalization & & & $\begin{array}{l}0.077 \\
(0.98)\end{array}$ & & & $\begin{array}{l}0.041 \\
(0.81)\end{array}$ \\
\hline Constant & $\begin{array}{c}0.792^{* *} \\
(2.53)\end{array}$ & $\begin{array}{l}0.589 \\
(1.51)\end{array}$ & $\begin{array}{l}0.381 \\
(0.85)\end{array}$ & $\begin{array}{c}0.796^{* * *} \\
(3.62)\end{array}$ & $\begin{array}{c}0.679 * * \\
(2.34)\end{array}$ & $\begin{array}{c}0.650 * * \\
(2.22)\end{array}$ \\
\hline Observations & 92 & 85 & 85 & 108 & 96 & 96 \\
\hline R-squared & 0.676 & 0.664 & 0.667 & 0.771 & 0.808 & 0.811 \\
\hline F-test for 1st stage & 17.83 & 12.90 & 12.53 & 22.33 & 25.09 & 21.55 \\
\hline Hansen J statistic (p-value) & 0.975 & 0.877 & 0.929 & 0.156 & 0.171 & 0.162 \\
\hline
\end{tabular}

Notes: Given data availability, the time period for tax mix analysis is 1995-2009, while the time period for tax complexity analysis is 2006-2009. Robust t-statistics in parentheses. ***,**, * denote significance at the 1,5 , and $10 \%$ level, respectively. 
Table 5: Robustness Checks: Alternative Measures of Corruption, 2SLS

\begin{tabular}{|c|c|c|c|c|c|c|c|c|}
\hline & \multicolumn{4}{|c|}{ WGI } & \multicolumn{4}{|c|}{ ICRG } \\
\hline & (1) & $(2)$ & $(3)$ & $(4)$ & $(5)$ & $(6)$ & (7) & $(8)$ \\
\hline Tax mix (primary) & $\begin{array}{c}-0.115^{* *} \\
(-2.47)\end{array}$ & $\begin{array}{c}-0.186^{* * *} \\
(-3.62)\end{array}$ & & & $\begin{array}{c}-0.138^{* * *} \\
(-2.75)\end{array}$ & $\begin{array}{c}-0.205^{* * *} \\
(-3.09)\end{array}$ & & \\
\hline Ln tax time requirement & & & $\begin{array}{c}0.129^{* * *} \\
(6.90)\end{array}$ & $\begin{array}{c}0.170^{* * *} \\
(5.40)\end{array}$ & & & $\begin{array}{c}0.055^{* *} \\
(2.23)\end{array}$ & $\begin{array}{c}0.091^{*} \\
(1.64)\end{array}$ \\
\hline Ln GDP & $\begin{array}{l}0.003 \\
(0.21)\end{array}$ & $\begin{array}{l}0.010 \\
(0.75)\end{array}$ & $\begin{array}{c}-0.022^{* * *} \\
(-2.77)\end{array}$ & $\begin{array}{c}-0.026^{* * *} \\
(-3.27)\end{array}$ & $\begin{array}{l}0.007 \\
(0.45)\end{array}$ & $\begin{array}{l}0.015 \\
(0.80)\end{array}$ & $\begin{array}{c}-0.044^{* * *} \\
(-4.08)\end{array}$ & $\begin{array}{c}-0.044^{* * *} \\
(-4.50)\end{array}$ \\
\hline Ln population density & $\begin{array}{l}-0.013 \\
(-1.16)\end{array}$ & $\begin{array}{l}-0.002 \\
(-0.17)\end{array}$ & $\begin{array}{l}-0.002 \\
(-0.21)\end{array}$ & $\begin{array}{l}-0.003 \\
(-0.26)\end{array}$ & $\begin{array}{l}-0.004 \\
(-0.24)\end{array}$ & $\begin{array}{l}0.002 \\
(0.11)\end{array}$ & $\begin{array}{l}0.017 \\
(1.30)\end{array}$ & $\begin{array}{l}0.014 \\
(0.92)\end{array}$ \\
\hline Openness & $\begin{array}{l}0.091 \\
(0.94)\end{array}$ & $\begin{array}{l}-0.010 \\
(-0.11)\end{array}$ & $\begin{array}{l}-0.043 \\
(-0.73)\end{array}$ & $\begin{array}{l}-0.027 \\
(-0.48)\end{array}$ & $\begin{array}{l}0.089 \\
(0.68)\end{array}$ & $\begin{array}{l}0.051 \\
(0.40)\end{array}$ & $\begin{array}{c}-0.146^{* *} \\
(-2.19)\end{array}$ & $\begin{array}{l}-0.112 \\
(-1.47)\end{array}$ \\
\hline Democracy & $\begin{array}{c}-0.232^{* * *} \\
(-4.70)\end{array}$ & $\begin{array}{c}-0.138^{* *} \\
(-2.32)\end{array}$ & $\begin{array}{c}-0.243^{* * *} \\
(-7.07)\end{array}$ & $\begin{array}{c}-0.206^{* * *} \\
(-5.34)\end{array}$ & $\begin{array}{c}-0.143^{* *} \\
(-2.34)\end{array}$ & $\begin{array}{l}-0.094 \\
(-1.25)\end{array}$ & $\begin{array}{c}-0.231^{* * *} \\
(-5.30)\end{array}$ & $\begin{array}{c}-0.166^{* * *} \\
(-2.79)\end{array}$ \\
\hline Government size & $\begin{array}{l}-0.015 \\
(-0.05)\end{array}$ & $\begin{array}{l}0.261 \\
(0.75)\end{array}$ & $\begin{array}{l}-0.081 \\
(-0.27)\end{array}$ & $\begin{array}{l}0.218 \\
(0.91)\end{array}$ & $\begin{array}{l}0.547 \\
(1.44)\end{array}$ & $\begin{array}{l}0.183 \\
(0.42)\end{array}$ & $\begin{array}{l}0.622^{*} \\
(1.78)\end{array}$ & $\begin{array}{l}0.170 \\
(0.42)\end{array}$ \\
\hline Ln Internet & $\begin{array}{c}-0.041^{* *} \\
(-2.45)\end{array}$ & $\begin{array}{c}-0.087^{* * *} \\
(-4.01)\end{array}$ & $\begin{array}{c}-0.038^{* * *} \\
(-3.06)\end{array}$ & $\begin{array}{c}-0.047^{* * *} \\
(-2.59)\end{array}$ & $\begin{array}{c}-0.032^{*} \\
(-1.74)\end{array}$ & $\begin{array}{c}-0.101^{* * *} \\
(-4.03)\end{array}$ & $\begin{array}{l}0.002 \\
(0.16)\end{array}$ & $\begin{array}{l}-0.032 \\
(-1.47)\end{array}$ \\
\hline Federal dummy & $\begin{array}{l}0.048 \\
(1.27)\end{array}$ & $\begin{array}{l}0.036 \\
(1.07)\end{array}$ & $\begin{array}{l}0.031 \\
(1.09)\end{array}$ & $\begin{array}{l}0.013 \\
(0.44)\end{array}$ & $\begin{array}{l}0.056 \\
(1.38)\end{array}$ & $\begin{array}{l}0.058 \\
(1.45)\end{array}$ & $\begin{array}{l}0.051 \\
(1.07)\end{array}$ & $\begin{array}{l}0.004 \\
(0.09)\end{array}$ \\
\hline Inflation & & $\begin{array}{c}0.010^{* *} \\
(2.45)\end{array}$ & & $\begin{array}{c}0.001^{* *} \\
(2.44)\end{array}$ & & $\begin{array}{c}0.014^{* *} \\
(2.55)\end{array}$ & & $\begin{array}{c}0.003^{* * *} \\
(3.53)\end{array}$ \\
\hline Human capital & & $\begin{array}{c}0.034^{* * *} \\
(3.21)\end{array}$ & & $\begin{array}{l}0.005 \\
(0.69)\end{array}$ & & $\begin{array}{c}0.041^{* * *} \\
(3.61)\end{array}$ & & $\begin{array}{l}0.012 \\
(1.44)\end{array}$ \\
\hline Female labor participation & & $\begin{array}{c}-0.150^{*} \\
(-1.65)\end{array}$ & & $\begin{array}{c}-0.194^{* * *} \\
(-2.69)\end{array}$ & & $\begin{array}{c}-0.180^{*} \\
(-1.68)\end{array}$ & & $\begin{array}{c}-0.353^{* * *} \\
(-3.70)\end{array}$ \\
\hline Legal origin & & $\begin{array}{l}-0.029 \\
(-0.48)\end{array}$ & & $\begin{array}{l}0.035 \\
(1.10)\end{array}$ & & $\begin{array}{l}0.036 \\
(0.56)\end{array}$ & & $\begin{array}{l}0.092^{*} \\
(1.73)\end{array}$ \\
\hline Colonial dummy & & $\begin{array}{l}-0.027 \\
(-0.41)\end{array}$ & & $\begin{array}{l}-0.035 \\
(-1.02)\end{array}$ & & $\begin{array}{l}-0.057 \\
(-0.67)\end{array}$ & & $\begin{array}{l}-0.067 \\
(-1.37)\end{array}$ \\
\hline Ethnic fractionalization & & $\begin{array}{l}0.055 \\
(0.83)\end{array}$ & & $\begin{array}{l}0.045 \\
(0.85)\end{array}$ & & $\begin{array}{l}-0.058 \\
(-0.79)\end{array}$ & & $\begin{array}{l}0.026 \\
(0.37)\end{array}$ \\
\hline Constant & $\begin{array}{c}0.789^{* * *} \\
(2.83)\end{array}$ & $\begin{array}{l}0.499 \\
(1.36)\end{array}$ & $\begin{array}{c}0.605^{* * *} \\
(2.95)\end{array}$ & $\begin{array}{l}0.484^{*} \\
(1.83)\end{array}$ & $\begin{array}{l}0.573 \\
(1.54)\end{array}$ & $\begin{array}{l}0.400 \\
(0.85)\end{array}$ & $\begin{array}{c}1.431^{* * *} \\
(5.15)\end{array}$ & $\begin{array}{c}1.391^{* * * *} \\
(3.45)\end{array}$ \\
\hline Observations & 92 & 85 & 108 & 96 & 81 & 76 & 94 & 85 \\
\hline $\mathrm{R}$-squared & 0.730 & 0.750 & 0.740 & 0.789 & 0.584 & 0.594 & 0.539 & 0.644 \\
\hline F-test for 1st stage & 17.83 & 12.53 & 22.33 & 21.55 & 19.25 & 10.53 & 23.69 & 19.89 \\
\hline Hansen J statistic (p-value) & 0.727 & 0.778 & 0.201 & 0.211 & 0.412 & 0.586 & 0.233 & 0.163 \\
\hline
\end{tabular}

Notes: Given data availability, the time period for tax mix analysis is 1995-2009, while the time period for tax complexity analysis is 2006-2009. Robust t-statistics in parentheses. ${ }^{* * *},{ }^{* *},{ }^{*}$ denote significance at the 1,5 , and $10 \%$ level, respectively. 
Table 6: Robustness Checks: Alternative Measures of Tax Structure, 2SLS

\begin{tabular}{|c|c|c|c|c|c|c|}
\hline & \multicolumn{4}{|c|}{ Tax Mix } & \multicolumn{2}{|c|}{ Tax Complexity } \\
\hline & (1) & $(2)$ & (3) & (4) & (5) & (6) \\
\hline Tax mix (alternative) & $\begin{array}{c}-0.158^{* * *} \\
(-3.59)\end{array}$ & $\begin{array}{c}-0.220^{* * *} \\
(-4.07)\end{array}$ & & & & \\
\hline PITRate & & & $\begin{array}{c}-0.005^{*} \\
(-1.81)\end{array}$ & $\begin{array}{c}-0.006^{* *} \\
(-2.31)\end{array}$ & & \\
\hline Ln tax payments & & & & & $\begin{array}{c}0.288^{* * *} \\
(3.47)\end{array}$ & $\begin{array}{c}0.282^{* * *} \\
(2.72)\end{array}$ \\
\hline Ln GDP & $\begin{array}{l}0.027 \\
(1.35)\end{array}$ & $\begin{array}{c}0.040^{*} \\
(1.67)\end{array}$ & $\begin{array}{l}-0.010 \\
(-0.66)\end{array}$ & $\begin{array}{l}-0.003 \\
(-0.21)\end{array}$ & $\begin{array}{l}0.012 \\
(0.78)\end{array}$ & $\begin{array}{l}0.014 \\
(0.69)\end{array}$ \\
\hline Ln population density & $\begin{array}{l}-0.013 \\
(-1.02)\end{array}$ & $\begin{array}{l}0.007 \\
(0.41)\end{array}$ & $\begin{array}{l}0.006 \\
(0.51)\end{array}$ & $\begin{array}{l}0.018 \\
(1.43)\end{array}$ & $\begin{array}{l}-0.011 \\
(-0.66)\end{array}$ & $\begin{array}{l}-0.007 \\
(-0.41)\end{array}$ \\
\hline Openness & $\begin{array}{l}0.143 \\
(1.37)\end{array}$ & $\begin{array}{l}-0.011 \\
(-0.10)\end{array}$ & $\begin{array}{l}-0.123 \\
(-1.26)\end{array}$ & $\begin{array}{l}-0.075 \\
(-0.71)\end{array}$ & $\begin{array}{l}-0.100 \\
(-1.40)\end{array}$ & $\begin{array}{l}-0.111 \\
(-1.64)\end{array}$ \\
\hline Democracy & $\begin{array}{c}-0.122^{*} \\
(-1.77)\end{array}$ & $\begin{array}{l}-0.029 \\
(-0.35)\end{array}$ & $\begin{array}{c}-0.192^{* * *} \\
(-3.96)\end{array}$ & $\begin{array}{c}-0.131^{*} \\
(-1.92)\end{array}$ & $\begin{array}{c}-0.211^{* * *} \\
(-3.76)\end{array}$ & $\begin{array}{c}-0.239^{* * *} \\
(-3.54)\end{array}$ \\
\hline Government size & $\begin{array}{l}0.248 \\
(0.70)\end{array}$ & $\begin{array}{l}0.634 \\
(1.35)\end{array}$ & $\begin{array}{l}0.253 \\
(0.68)\end{array}$ & $\begin{array}{l}0.231 \\
(0.64)\end{array}$ & $\begin{array}{l}-0.181 \\
(-0.58)\end{array}$ & $\begin{array}{l}0.161 \\
(0.40)\end{array}$ \\
\hline Ln Internet & $\begin{array}{c}-0.049^{* * * *} \\
(-2.86)\end{array}$ & $\begin{array}{c}-0.105^{* * *} \\
(-3.98)\end{array}$ & $\begin{array}{c}-0.065^{* * *} \\
(-3.90)\end{array}$ & $\begin{array}{c}-0.089 * * * \\
(-4.75)\end{array}$ & $\begin{array}{l}-0.007 \\
(-0.39)\end{array}$ & $\begin{array}{l}-0.028 \\
(-1.20)\end{array}$ \\
\hline Federal dummy & $\begin{array}{c}0.106^{* *} \\
(2.09)\end{array}$ & $\begin{array}{c}0.084^{*} \\
(1.70)\end{array}$ & $\begin{array}{l}0.028 \\
(0.53)\end{array}$ & $\begin{array}{l}0.024 \\
(0.50)\end{array}$ & $\begin{array}{l}-0.030 \\
(-0.56)\end{array}$ & $\begin{array}{l}-0.015 \\
(-0.25)\end{array}$ \\
\hline Inflation & & $\begin{array}{l}0.008 \\
(1.55)\end{array}$ & & $\begin{array}{c}0.167^{* * *} * \\
(3.85)\end{array}$ & & $\begin{array}{l}-0.001 \\
(-1.04)\end{array}$ \\
\hline Human capital & & $\begin{array}{c}0.048^{* * * *} \\
(2.94)\end{array}$ & & $\begin{array}{l}0.005 \\
(0.56)\end{array}$ & & $\begin{array}{l}0.017 \\
(1.27)\end{array}$ \\
\hline Female labor participation & & $\begin{array}{l}-0.162 \\
(-1.25)\end{array}$ & & $\begin{array}{l}-0.153 \\
(-1.57)\end{array}$ & & $\begin{array}{l}0.042 \\
(0.26)\end{array}$ \\
\hline Legal origin & & $\begin{array}{l}0.040 \\
(0.47)\end{array}$ & & $\begin{array}{l}-0.045 \\
(-0.90)\end{array}$ & & $\begin{array}{l}-0.045 \\
(-0.93)\end{array}$ \\
\hline Colonial dummy & & $\begin{array}{l}-0.117 \\
(-1.34)\end{array}$ & & $\begin{array}{l}-0.036 \\
(-0.65)\end{array}$ & & $\begin{array}{l}0.049 \\
(0.74)\end{array}$ \\
\hline Ethnic fractionalization & & $\begin{array}{l}0.155^{*} \\
(1.74)\end{array}$ & & $\begin{array}{l}0.102^{*} \\
(1.71)\end{array}$ & & $\begin{array}{l}0.031 \\
(0.38)\end{array}$ \\
\hline Constant & $\begin{array}{l}0.279 \\
(0.61)\end{array}$ & $\begin{array}{l}-0.292 \\
(-0.44)\end{array}$ & $\begin{array}{c}1.218^{* * *} \\
(3.58)\end{array}$ & $\begin{array}{c}1.010^{* * *} \\
(2.86)\end{array}$ & $\begin{array}{l}-0.380 \\
(-0.63)\end{array}$ & $\begin{array}{l}-0.512 \\
(-0.60)\end{array}$ \\
\hline Observations & 92 & 85 & 101 & 93 & 107 & 96 \\
\hline R-squared & 0.634 & 0.610 & 0.616 & 0.647 & 0.452 & 0.468 \\
\hline F-test for 1 st stage & 11.62 & 6.792 & 7.331 & 7.663 & 11.173 & 19.201 \\
\hline Hansen J statistic (p-value) & 0.970 & 0.856 & 0.754 & 0.370 & 0.560 & 0.505 \\
\hline
\end{tabular}

Notes: Given data availability, the time periods for tax mix, top statutory personal income tax rate, and tax complexity analysis are 1995-2009, 1995-2005, and 2006-2009, respectively. Robust t-statistics in parentheses. $* * *, * *, *$ denote significance at the 1,5 , and $10 \%$ level, respectively. 


\section{Appendix}

Table A1: Description of Variables and Sources

\begin{tabular}{|c|c|c|}
\hline Variable & Description & Source \\
\hline Corruption, TI index & $\begin{array}{l}\text { Corruption index, originally ranging from } 0 \text { to } 10 \text {, with } \\
10 \text { indicating the lowest corruption. It is rescaled to take } \\
\text { values between } 0 \text { and } 1 \text { with } 0=\text { least corruption. }\end{array}$ & Transparency International \\
\hline Corruption, WGI index & $\begin{array}{l}\text { Corruption index, originally ranging from }-2.5 \text { to } 2.5 \text {, with } \\
2.5 \text { indicating the lowest corruption. It is rescaled to take } \\
\text { values between } 0 \text { and } 1 \text { with } 0=\text { least corruption. }\end{array}$ & $\begin{array}{l}\text { Worldwide Governance Indi- } \\
\text { cators }\end{array}$ \\
\hline Corruption, ICRG index & $\begin{array}{l}\text { Corruption index, originally ranging from } 0 \text { to } 6 \text {, with } 6 \text { in- } \\
\text { dicating the lowest corruption. It is rescaled to take values } \\
\text { between } 0 \text { and } 1 \text { with } 0=\text { least corruption. }\end{array}$ & $\begin{array}{l}\text { International Country Risk } \\
\text { Guide }\end{array}$ \\
\hline Tax mix (primary) & $\begin{array}{l}\text { Direct (personal and corporate income tax, payroll tax, so- } \\
\text { cial security contributions) to indirect (property tax, gen- } \\
\text { eral taxes on goods and services, excise taxes, custom du- } \\
\text { ties) tax ratio. }\end{array}$ & $\begin{array}{l}\text { Government Finance Statis- } \\
\text { tics (GFS), OECD Revenue } \\
\text { Statistics }\end{array}$ \\
\hline Tax mix (alternative) & $\begin{array}{l}\text { Direct (personal and corporate income tax, payroll tax, so- } \\
\text { cial security contributions, property tax) to indirect (taxes } \\
\text { on goods and services, excise taxes, custom duties) tax ra- } \\
\text { tio. }\end{array}$ & $\begin{array}{l}\text { GFS, OECD Revenue Statis- } \\
\text { tics }\end{array}$ \\
\hline PITRate & Top statutory tax rate of personal income tax, $\%$ & World Tax Indicators \\
\hline Tax time requirement & $\begin{array}{l}\text { Time to prepare, file and pay corporate, sales, labor, and } \\
\text { other taxes. }\end{array}$ & $\begin{array}{l}\text { World Bank Doing Business } \\
\text { Data }\end{array}$ \\
\hline Tax payments & $\begin{array}{l}\text { Total number of taxes paid, method of payment, frequency } \\
\text { of payment and number of agencies involved. }\end{array}$ & $\begin{array}{l}\text { World Bank Doing Business } \\
\text { Data }\end{array}$ \\
\hline GDP & Real GDP in constant 2000 dollars, log & $\begin{array}{l}\text { World Development Indica- } \\
\text { tors (WDI) }\end{array}$ \\
\hline Population density & People per sq. $\mathrm{km}$ of land area, log & WDI \\
\hline Openness & Share of import in GDP. & WDI \\
\hline Democracy & $\begin{array}{l}\text { Average of political right index and civil liberties index. It } \\
\text { is rescaled to take values between } 0 \text { and } 1 \text { with the larger } \\
\text { value implying more democratic. }\end{array}$ & Freedom House \\
\hline Government size & Share of government consumption in GDP. & Penn World Tables \\
\hline Internet & The number of Internet users per 100 people, log & WDI \\
\hline Federal dummy & $=1$ if federal constitution, 0 otherwise. & $\begin{array}{l}\text { Quality of Government } \\
\text { Dataset }(\mathrm{QGD})^{1}\end{array}$ \\
\hline Decentralization & Subnational share of total government spending. & $\begin{array}{l}\text { World Bank's Decentraliza- } \\
\text { tion Indicators }\end{array}$ \\
\hline Inflation & Annual percent change in consumer prices, $1 / 100$ & WDI \\
\hline Human capital & Average years of schooling. & Barro and Lee (2010) \\
\hline Female labor participation & $\begin{array}{l}\text { The proportion of the population ages } 15 \text { and older that is } \\
\text { economically active, } \%\end{array}$ & WDI \\
\hline Legal origin & $=1$ if legal origin of English Common Law, 0 otherwise. & QGD \\
\hline Colonial dummy & $=1$ if country was a British colony, 0 otherwise. & QGD \\
\hline Ethnic fractionalization & $\begin{array}{l}\text { The probability that two random selected individuals } \\
\text { within the country belong to the same religious and ethnic } \\
\text { group. Continuous variable between } 0 \text { and } 1 \text {. }\end{array}$ & QGD \\
\hline
\end{tabular}

